\title{
The Impact of Covid-19 to Indonesian Education and Its Relation to the Philosophy of "Merdeka Belajar"
}

\author{
A Abidah ${ }^{1 *}$, H N Hidaayatullaah ${ }^{2}$, R M Simamora ${ }^{3}$, D Fehabutar $^{4}$, L Mutakinati $^{5}$ \\ 1Pharmacy Vocational High School of Sekesal, Surabaya, Indonesia \\ 2,4Physics Education Program, Universitas Negeri Surabaya, Surabaya, Indonesia \\ ${ }^{3}$ Indonesia Institute of the Art, Yogyakarta, Indonesia \\ ${ }^{5}$ Graduate School of Science and Technology, Shizuoka University, Japan
}

\section{Article Info \\ Article history: \\ Received March 29, 2020 \\ Revised April 1, 2020 \\ Accepted April 1, 2020}

Keywords:

Covid-19

Philosophy of education

Merdeka Belajar

\begin{abstract}
The Covid-19 pandemic is now beginning to spread to the world of education. The Ministry of Education and Culture (MOEC) is currently based on official information, ready with all scenarios, including encouraging online learning for students. This article is a kind of position paper-it clearances one side of a debatable opinion about a hot issue. The aim of a position paper is to persuade the reader that our opinion is valid and defensible. In regards to our position as researchers, then, the point of view is separated into four parts: The philosophy of "Merdeka Belajar"; physical distancing, social distancing and self-quarantine; digital learning in Indonesia to face Covid-19; 'Merdeka Belajar', digital learning, Covid-19, and authors' view.
\end{abstract}

\section{INTRODUCTION}

The impact of the Corona virus disease 2019 (Covid-19) pandemic is now beginning to spread to the world of education. This is done as an effort to prevent the spread of Covid-19 transmission. It is hoped that all educational institutions will not carry out activities as usual; this can diminish the spread of Covid-19. The same thing has been done by various countries that are exposed to this disease, lockdown or quarantine policies carried out in an effort to reduce the interaction of many people who can provide access to the spread of the Covid-19.

The spread of the Covid-19 had a profound effect on the economic world which was starting to fade, but now the impact is being felt by the education world. The policies taken by many countries including Indonesia by dismissing all educational activities make the government and related institutions must present alternative educational processes for students and students who cannot carry out the educational process in educational institutions.

In Indonesia, the number of Covid-19 positive patients per Sunday (29/3), increased to 1285 people (covid19.go.id). As many as 114 of them died, and 64 people were declared cured. The cases came from DKI Jakarta (675), West Java (149), Banten (106), East Java (90), Central Java (63), South Sulawesi (47), DIY (22), East Kalimantan (17), Bali (10), Papua (9), North Sumatera (8), West Kalimantan (8), Central Kalimantan (7), Aceh (5), West Sumatera (5), Riau Islands (5), Lampung (4), Southeast Sulawesi (3), Riau (2), South Sumatera (2), NTB (2), North Kalimantan (2), North Sulawesi (2), Central Sulawesi (2), West Papua (2), Jambi (1), South Kalimantan (1), West Sulawesi (1), Maluku (1), North Maluku (1), and in the process of investigating 33 cases (covid19.go.id).

Based on data obtained from UNESCO, more than 160 countries have implemented national closures, affecting more than half the world's student population. The latest 
statistics from UNESCO (25/03/2020) mentioned that 1,524,648,768 students were affected by the covid-19 virus from $87,1 \%$ of the total students enrolled. So far India and China have the largest number of students affected by the covid-19 virus, which is more than 270 million students, and in Indonesia per Wednesday (25/3) as many as 68,265,787 students affected by Covid-19 (UNESCO, 2020). While other countries, 165 countries in Africa, Asia, Europe, the Middle East, North America, and South America have announced or imposed restrictions on school and university learning. UNESCO provides direct support to countries, including solutions for inclusive distance learning. UNESCO together with each country works together to ensure continuity of learning for all, especially disadvantaged children and adolescents who tend to be hardest hit by school closures (UNESCO, 2020).

The total number of students who are potentially at risk from pre-primary to high school education is $577,305,660$. On the other hand, the number of students who are potentially at risk from higher education is 86,034,287 people (Nugroho, 2020). Currently in Indonesia, several universities are starting to implement policies on teaching and learning activities from a distance or online lectures. This is actually not a problem for universities that already have an online academic system. But it will be a problem for universities that do not yet have an online academic system.

The Ministry of Education and Culture (MOEC) is currently based on official information, ready with all scenarios including the application of working together to encourage online learning (in networks) for students. In an effort to keep students studying at home, the MOEC has prepared a number of supports to smooth the process. They develop distance learning applications based on android: "portal Rumah Belajar" (Kemdikbud, 2020). This portal can be accessed at learning.kemdikbud.go.id. Some excellent features that can be accessed by students and teachers include learning resources, digital classes, virtual laboratories, and question banks. Learning centers can be utilized by students and teachers of Early Childhood Education, Elementary Schools, Junior High Schools, Senior High Schools or Vocational Schools or equivalent.

Currently based on information that the MOEC has joined forces with seven online learning platforms namely Smart Classes, Quipper, Google Indonesia, Sekolahmu, Zenius, and Microsoft. Each platform will provide facilities that are publicly accessible and free.Some online learning platforms that can be accessed by students and teachers to increase learning resources include Google Indonesia, Sekolahmu, Smart Classes, Zenius, Quipper, and Microsoft.

The covid-19 pandemic is indeed a tough test for all nations, testing the ability of all nations to be able to take wisdom by continuing to strive and endeavor to find solutions to every problem that exists. As a big nation, Indonesia must be able to overcome all existing problems. This is evidenced by Indonesia ready with all possibilities, with the birth of technologies created by the nation's children to provide online education services.

This paper presents a position or view of the authors regarding the influence of the covid-19 plague on education and its relation to the philosophy of freedom of learning promoted by the MOEC. The authors present various debates surrounding the implementation of learning process in the context of online learning when this virus is endemic.

\section{METHOD OF ANALYSIS}

This article is kind of position paper. It represents one side of an arguable opinion about an issue, like the situation in a debate. Some previous researchers' used term 'conceptual analyses in methodology (Abdul Razzak, 2020). The aim of a position paper is to persuade the reader that our opinion is valid and defensible. It is very important to guarantee that we are considering all edges of the issue and awarding it in a manner that is easy for our reader to recognize (Guilford,2001; Suprapto, 2016). The following is the step in writing a position 
paper: (1) Select a topic for our paper; (2) Conduct preliminary research; (3) Challenge our topic; (4) Continue to collect supporting evidence; and (5) Create an outline (Fleming, 2020). The authors were also adopted the systematic review by Suprapto, Liu, \& Ku (2017). The study was also part of sponteneous study based on the trending issue in the world (Suprapto, Deta, Lestari, Kholiq, Adam, Mubarok, \&Jauhariyah, 2018). Therefore, in order to support the ideas and argument, three teachers, five students, three parents, and two faculty members were interviewed.

\section{POINT OF VIEW AND DISCUSSION}

\section{The Philosophy of "Merdeka Belajar"}

Indonesian Minister of Education and Culture, Nadiem Makarim established four national learning programs. He calls these four programs education policies "Merdeka Belajar" (Kemdikbud, 2019). The program includes the National Standard School Examination (USBN), National Examination (UN), one sheet of Lesson Plan (RPP), and Zoning Regulations for New Student Acceptance (PPDB) (see Figure 1).

4 INITIATIVE MERDEKA BELAJAR -By NADIEM MAKARIM

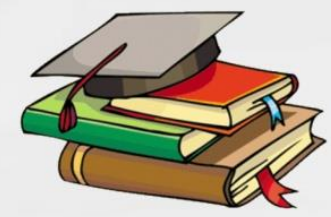

Replace the National Standard School Examination (USBN)

The National Standard School Examination so far determine the graduation of school students. Schools are free to make examination autonomously.

Remove the National Examination (UN)

National Examination will be abolished in 2021, replaced by the Minimum Competency Assessment and Character Survey. The UN substitute examination will be held in the middle of the level, not at the end of the level like the current UN.

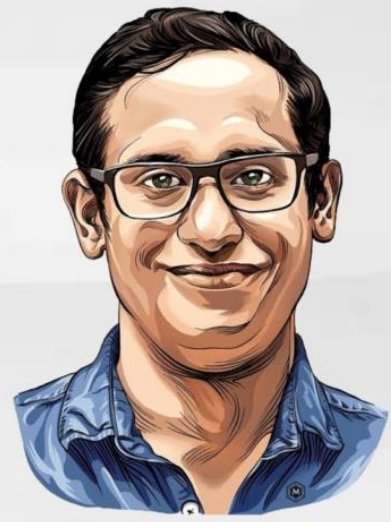

One Sheet of Lesson Plan

The Lesson Plan (RPP) has so far contained 11 components covering subject identity, competency standards, basic competencies, basic material, and time allocation. The RPP is simplified into 1 sheet.

Loosen Zoning

Zoning regulations for New Student Acceptance (PPDB) is loosened up, the quota of outstanding students who were previously $15 \%$ increased to $30 \%$. Student quota in the school zone is reduced from $80 \%$ to $50 \%$.

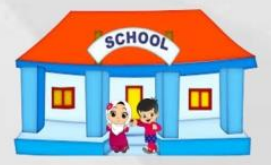

Figure 1. The concept of 'Merdeka Belajar' 
This paper is not in a position to elaborate on the intent of the MOEC's "Merdeka Belajar" program, but the authors express their views related to the term 'merdeka hidup' and 'merdeka belajar'. The philosophy of the term is derived from the principle of the creation of an independent human being. Among the various creatures of God, with the facilities of reason, humans are free beings to choose their own path, both the path of good and the way of evil.

There is no one or anything that forces or hinders humans from determining these two paths. God only provides facilities in the form of life (spirit) and organs (as tools) that humans can use to choose their path. Therefore, as an independent being, human beings must be responsible for their actions and he has no reason to corner God in the crimes he committed. And good education must pay attention to the principle of independence which is the best gift given by God to humans, so education cannot be contrary to the principle of human freedom.

Merdeka belajar means freedom of learning, which is to give students the opportunity to learn as freely and freely as they can to learn calmly, relax and happily without stress and pressure by paying attention to their natural talents, without forcing them to learn or master a field of knowledge in outside their hobbies and abilities, so that each of them has a portfolio that suits their passion. Because, giving a burden to students beyond their ability is an act that is deplorable in common sense and impossible for wise teachers to do. This is like a blind student and the teacher asks him to tell what and how the sun is to his friends. If freedom of learning is fulfilled, it will create "independent learning" or "independent learning" and the school is called an independent school or a free school.

This reminds the writer of Paolo Freire, a Brazilian educator from Recife University. As a law student, but he also studied philosophy and psychology in language. Even though he graduated as a legal expert, he never really practiced in that field. Instead he worked as a teacher in secondary schools, teaching Portuguese. His famous teaching is that man is the ruler of himself, and therefore human nature is to be free. This is the final goal of Freire's humanization efforts. Humanization, therefore, also means the liberation or liberation of human beings from oppressive boundary situations which they want. "The oppressed must free and liberate themselves from inhuman oppression while at the same time freeing the oppressors from prison of conscience who do not honestly oppress" (Abdul Razzak, 2020; Belliappa, 2020). If there are still exceptions, true freedom and freedom will never be achieved in full and meaningfully (Freire, 1968). Currently, the freedom of education lies the notion of a new humanism (Marope, 2017).

In the level of university, the MOEC implement 'kampus merdeka' or the independent university, as figure out in Figure 2. 


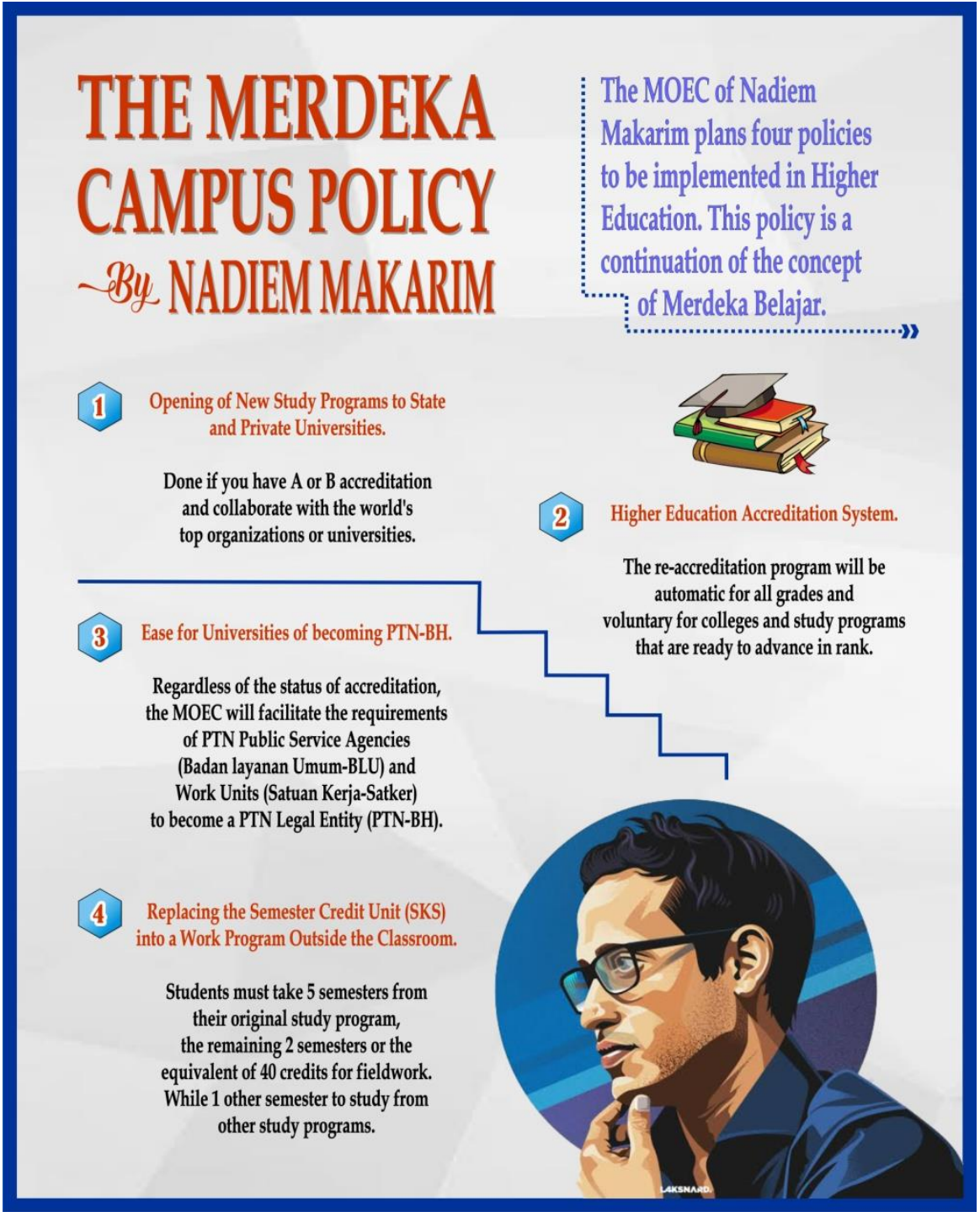

Figure 2.The ilustration of 'Kampus Merdeka'

The Merdeka Campus policy is a continuation of the concept of Merdeka Belajar. Its implementation only changes ministerial regulations, not to change Government Regulations or Laws. There are four main points:

1. Opening of new study programs

This program gives autonomy to state and private universities to open new study programs. But this autonomy is not free. Public and private universities must have A and B accreditation, and they have collaborated with universities included in QS Top 100 World Universities with exceptions for health and education study programs. The MOEC will work closely with universities and study program partners to conduct surveillance. Meanwhile, tracer studies must be done every year. Then, higher education (HE) is obliged to ensure this is applied.

2. Higher education accreditation system

The re-accreditation program will be automatic for all grades and voluntary for colleges and study programs that are ready to advance in rank. While accreditation that has been established by the National Accreditation Board for Higher Education (BAN-PT), remains valid for 5 years but will be renewed automatically. Submission of HE and Study Program accreditation is limited to 2 years after the previous accreditation.

3. Ease for universities of becoming PTN-BH 
This policy is related to freedom for public university (PTN) as Public Service Agency (Badan Layanan Umum-BLU) and Work Unit (Satuan Kerja-Satker) to become PTN Legal Entity $(P T N-B H)$. The MOEC will simplify its requirements without being bound by accreditation status.

4. Study rights for 3 semesters outside the study program

Undergraduate students can take courses outside their study program. It means the government changes the definition of Semester Credit Unit (SKS). Higher education must provide the right for students to volunteer, so students can take or not take credits outside the campus for two semesters or equal to 40 credits. Additionally, students can also take SKS in other study programs on campus as much as one semester from the total semester that must be taken. However, the policy does not apply to health study programs. The meaning of SKS is defined as 'hours of activity', no longer 'hours of study'. The activities in question are activities in class, internships, industrial work practices, research, independent studies, and others.

Ki Hajar Dewantara emphasized repeatedly about freedom of learning. "... independence should be imposed on the way children think, that is, do not always be" spearheaded", or told to acknowledge the thoughts of others, it will still be a habit for children to find out all their knowledge by using their own thoughts ..." Ki Hadjar Dewantara (Panitia, 1952). The child is basically able to think to "find" knowledge.

What does independence mean in his statement? In an article in the book Education, he stated "In education must always be remembered that independence is consist of three kinds: stand alone, not dependent on others, and can regulate yourself" (Setiawan, 2019). Independent learning characterizes critical, quality, express, transformative, effective, applicable, varied, progressive, actual, and factual learning. Students who learn based on independence will always be energetic, optimistic, prospective, creative, and always brave to try new ones. They are always hungry and thirsty for knowledge. Students in this category assume that reading nutritious books is no less enjoyable than eating food. They are challenged to face learning difficulties; they always want to be and never give up before trying, they do not depend on parents, teachers, schools and systems or rules. Wherever they are, they become individuals who are fun, influential and useful.

If we back to the Socratic classroom dialogue then we focus on the question, how should we begin learning?. A young man came to Socrates and said, "I want to study philosophy with you." Socrates answered, "You come with confidence?" The young man said, "Yes." Then Socrates brought the young man to the edge of the lake and said, "Put your head in it!" Then the young man put his head in the lake.

A moment later Socrates pulled the young man's neck and drowned him in the water. A few minutes later the young man almost fainted. Then he moved his hands to show that he could no longer hold his head. Then Socrates released his neck. The young man decapitated took his head out of the water. Then he asked why Socrates treated him this way? Socrates answered, "Under such conditions, what do you ask for with sincerity and all your heart?" The young man answered, "I just want air and that's all." Socrates said, "Now go to your house and think that if you come to a stage where you will seek and desire philosophy like this, you will seek philosophy with all your heart, then when it comes here so I will teach you philosophy."

This is the best parable of how to study. Then the question is whether we have learned to have reached this stage? The Sufis say, "Heart experts have two qualities: first is the heart that receives the conversation, and second, that is the conversation received by the heart." Find yourself in the sentence! Which one are you from? It's shocking to know that so many people don't believe they can learn, and even more believe that learning is difficult. 


\section{Social Distancing and Self-Quarantine}

When the Indonesian government suggests the concept of 'merdeka belajar', on the other hand, we should apply self-quarantine and social distancing in the situational of Covid-19 pandemic. "Social distancing is deliberately increasing the physical space between people to avoid spreading illness. Staying at least six feet away from other people lessens your chances of catching covid-19" (Maragakis, 2020).The examples of social distancing are: closing schools or substituting to online classes; working from home (WFH) instead of at the office; visiting loved ones by electronic devices instead of in person; and postponing or cancelling large meetings including conferences.

People who have been exposed to the new covid-19 virus and who are at risk for coming down with COVID-19 might practice self-quarantine. The duration of selfquarantine is 14 days. This period offers enough time for them to know whether or not they will become ill and be contagious to other people.

We might be asked to practice self-quarantine if we have recently returned from traveling to a part of the country or the world where COVID-19 is spreading rapidly, or if we have knowingly been exposed to an infected person. The examples of self-quarantine are not having visitors; staying at home; washing hands frequently; using standard hygiene and not sharing things like towels and utensils; staying at least 6 feet away from other people in our household (Maragakis, 2020). Once our quarantine period has ended, if we do not have symptoms, we should follow the doctor's instructions on how to return to our normal routine.

The last is isolation. "Isolation is a health care term that means keeping people who are infected with a contagious illness away from those who are not infected" (Maragakis, 2020). It can take place at a hospital, care facility or at home. Special personal protective equipment will be used to care for these patients in health care settings.

\section{Digital Learning in Indonesia to Face Covid-19}

A number of regions have decided to close schools to prevent the spread of corona virus. In order for students to continue studying at home, the Ministry of Education and Culture (MOEC) has prepared a number of supports to facilitate the process. MOEC itself develops distance learning applications based on portal and android "Rumah Belajar". This portal can be accessed at learning.kemdikbud.go.id.

Some excellent features that can be accessed by students and teachers include Learning Resources, Digital Classes, Virtual Laboratories, and Question Banks. Learning Centers can be utilized by students and teachers of Early Childhood Education, Elementary Schools, Junior High Schools, Senior High Schools and Vocational Schools or equivalent. The MOEC has partnered with seven online learning platforms, namely Smart Class, Ruangguru, Sekolahmu, Zenius, Quipper, Google Indonesia, and Microsoft. Each platform will provide facilities that are publicly accessible and free (Kemdikbud, 2020).

\section{Smart Class}

Smart Class supports the anticipatory steps of the MOEC to minimize the spread of Covid-19 in Indonesia. The temporary suspension of teaching and learning activities in schools, does not necessarily make the student learning process stalled. Students can keep learning online, teachers can continue to provide assistance in the learning process of students, and parents can monitor their children's learning progress. All that can be done with technology-based education solutions such as Smart Classes. During the next month, teachers and students throughout Indonesia can use online learning solutions from Smart Classes for free. So, the learning process of students continues, when and from anywhere. 


\section{Sekolahmu}

Sekolahmu has also organized classroom and career learning by collaborating with hundreds of schools and organizations. Online learning is intended for all students, teachers, and even parents. The programs provided by Sekolahmu have been very well designed by an experienced academic team in applying successful competency-based learning. It will provide home learning classes for all levels from pre-school to high school, as well as parents, in lieu of teaching and learning activities in schools that will be reduced or closed because Covid-19 is free. They also facilitate schools and teachers to remain can teach according to the curriculum needed flexibly (Kasih, 2020).

\section{Zenius}

Meanwhile, Zenius platform helped students prepare for the UN and UTBK. If previously learning independently was considered not directed and measurable, Zenius also formulated ways to help children learn independently at home that were effective and efficient, directed and measurable. The platform is ready to help smooth the learning process by providing free access to more than 80 thousand learning videos so that students can get a structured independent learning process. Zenius also give tryout every week for 9 class and 12 class students, so they can prepare for next study (to senior high school for 9 class and University for 12 class) even when they study at home (Fajrul, 2020).

\section{Quipper}

Quipper provides free access and materials to schools, teachers and students. Teachers and schools can also use the Quipper School service to provide assignments and examinations while monitoring student work. This includes videos, modules, and a collection of national exams (UN) questions and computer-based written exams (UTBK) of the state higher education independent selection (SBMPTN) for junior and senior high school teachers throughout Indonesia. This platform service is specifically for affected schools and will be available starting Tuesday, March 17, 2020 (Quipper, 2020).

\section{Google Indonesia}

Google helps students and teachers in Indonesia to be able to continue learning outside of school through G Suite for Education - a collaborative learning tool between teachers and students available free of charge from Google. Schools can use Hangouts Meet, a video conferencing tool available to all G Suite users, and Google Classroom, to attend classes and continue distance learning from home. Until July 1, 2020, Google provides the most complete Hangouts Meet feature free of charge which includes live streaming capabilities of up to 100,000 viewers in a domain and large gatherings of up to 250 participants per class until July 1, 2020 which can be recorded and stored on Google Drive for later access day."Through G Suite for Education, students can continue to study even when internet access is slow or unavailable and wherever they are" (Widianingtyas \& Sadino, 2020).

\section{Microsoft}

PT. Microsoft Indonesia provides Office 365 access for education. To take advantage of this facility, schools only need to provide an institutional domain as a digital identity of teachers and students. With the Teams facility in Office 365, the teaching and learning process can still take place digitally and the teacher can face to face with students through video conferencing facilities when needed. Teachers can send text, voice and video-based teaching materials through the team classes to their students. Likewise students can discuss with other teachers and students in the teams class (Widianingtyas \& Sadino, 2020). 
The public is also advised to take three important steps to counter the rapid spread of Covid-19. The three steps are reducing the risk of exposure to Covid-19, finding correct information related to Covid-19. To reduce the risk of corona virus exposure, the government appealed to the color for frequent hand washing using soap and running water as the first defense of the Corona virus.

We should wash our hands for a minimum of 20 seconds and remind our child to wash their hands with soap properly. Then, we must wash hands with soap when arriving at home, work or school, before eating, before preparing food, and after using the toilet. Another tip is to use hand sanitizer (at least 60\% alcohol) if soap and running water are not available. Additionally, we must cover our mouth and nose with our elbows folded when coughing or sneezing or use a tissue, which is immediately thrown into a closed trash can after use. Next, we should keep a distance of at least 1 meter from people. We must aware that we don't be near an unhealthy person and avoid touching the face because the mouth, nose, eyes can be the entrance of the virus. We are also asked to reduce direct contact (physical and social distancing). When people who are sick of Covid-19 are being isolated but spread the corona virus rapidly to their territory through close contact, then the pattern is called community transmission.

The more widespread community transmission occurs, then additional action needs to be taken, namely reducing contact between one citizen and other residents in the area (physical and social distancing or here will be referred to as reducing contact between residents). The following is a guide from experts about social distancing:

$\checkmark$ Avoid large gatherings (more than 10 people);

$\checkmark$ Do not go to health facilities unless needed. If we have a family member or friend hospitalized, limit visitors - especially if they are children or high risk groups (elderly people and people with a disease that can make it worse, such as heart problems, diabetes and other chronic diseases);

$\checkmark$ High-risk people should stay at home and avoid meetings or other activities that could expose them to viruses, including traveling;

$\checkmark$ Give support to family members (who do not live in your house) or infected neighbors without having to meet in person, for example by telephone or WA;

$\checkmark$ Follow official guidelines in our area that can change your routine including school or work activities;

$\checkmark$ Follow the development of information because the situation can change quickly according to the development of the disease and its spread;

$\checkmark$ Remember that if everyone does what must be done, we can all go through this and return to normal life.

\section{'Merdeka Belajar', Digital Learning, Covid-19 and Our Point of View}

God predestined the plague of Covid-19 not to be a coincidence. In the same situation Indonesia has also realized the necessity to implement a 'free learning' program. In the midst of situations, we require self-quarantine, physical, and social distancing. Therefore, for education to continue, distance education or online must absolutely be done. As described above various platforms have been prepared to support learning in the era of limitations. This condition gives opportunity to all parties both students and teachers to implement independence in learning. They are free to explore. Learning can be done anywhere, from the house, the room, the garden, the boarding room, or dormitory as long as the desire to think from humans is contained. Support online facilities ranging from social media, You Tube, Facebook, WhatsApp, Twitter, Google Classroom, Line, Zoom, Kahoot, Scoology, etc. make it easy for anyone to do independent learning. The following expressions are the additional ideas and opinions from students (S), teachers $(\mathrm{T})$, parents $(\mathrm{P})$, and faculty members (FM). 
"Covid-19 pandemic provides 'fresh air' for online learning media to show off." (FM1) "The concept of independent learning by chance is interpreted as free learning at home. but I worry, that means freedom beyond the limits." (P1) "Current conditions provide opportunities for businesses, especially selling data packages or internet packages." (T1)

"Frankly with the situation of my child where studying at home during the Covid-19 pandemic, it would be inconvenient for parents despite the ease of online learning facilities." (P2)

"I suggest to the government to do a lock down so that the eye between covid-19 can be stopped in Indonesia so that teaching and learning activities return to normal." (FM2)

"I tried to apply online learning in my course, but I felt it was still ineffective because of the elements of humanism, namely the interaction between lecturers and students was less humane. However, the concept of free learning gives a breath of fresh air that students can develop themselves including independent learning with existing online learning resource facilities". (FM1)

"To parents, we hope to keep an eye on the activities of children during this 14-day holiday, try to keep children at home, do not do activities outside the home and interact with many people, this is to prevent the spread of the virus that has now become a national pandemic." (T3)

"Please help explain to the public, so that all obedient and the government is helped to stop the transmission of Covid-19, if this is ignored then 14 days off is useless, even a year off cannot prevent Covid-19 transmission" (FM2)

"Students are only given the title of the material, they can use the gadget for learning, the teacher just needs to direct."(S1)

"Learning from home makes our academic burdens even more difficult, teachers tend not to teach but to give up"(S2)

"On the MOEC page, there is all subject matter. It can also learn from the Teacher's Room application" (T3)

"For two weeks, the teachers have the opportunity to tidy up the school, we have the opportunity to prevent and improve conditions, so that the next two weeks the school will be better prepared." (FM1)

"When my children learn from home, we have an opportunity to create a Family Library" (P3).

This last expression really touched the authors. If there are no operational instructions for learning from home, creating familiarity by creating a family library is a productive choice. It can be in the living room, a special study room, to a permanent room allocated for a private library. The way to do it together is to prepare a place for displaying books from family collections as in the library in general. Then, the various book collections are arranged according to the theme of the discussion. If it is about education, it means that the sub-row line specializes in the book. The goal is to make it easy to find, so when family members who finish reading will be returned to normal.

Moreover, if then other family members imitate to produce written works. Of course, creating literacy in the family is not limited to discourse. Literacy education but also has become a family planning program that is not limited to reading, but continued to write, in order to produce products or writing from the basic educational environment, namely the family. As a closing sentence, let's support the Indonesian government to implement responsible learning independence.

\section{CONCLUSION}

In general, Covid-19 has a significant impact on the world of education, including in educational system in Indonesia. Traditional and routine learning that emphasizes the interaction of teachers and students in the classroom and outside the classroom shifts to distance learning. Although this situation is in line with the vision and mission of future 
learning in the era of the industrial revolution 4.0 and community 5.0, it still has advantages and disadvantages. In terms of strengths, of course, online learning is not limited by space and time, especially since the government's call for self-quarantine, physical, and social distancing. However, the current freedom cannot be interpreted as unlimited freedom in learning. As we have already discussed above that there were four points in free learning and 4 main things in an independent campus. The last sentence of this paper, hopefully Covid-19 will end soon so that humanism in learning can be achieved as before.

\section{REFERENCES}

Abdul Razzak, N. (2020). Paulo Freire's critical and dialogic pedagogy and its implications for the Bahraini educational context. Educational Philosophy and Theory, (Article in press). https://doi.org/10.1080/00131857.2020.1716731

Belliappa, J. L. (2020). Extending feminist pedagogy in conferences: Inspiration from theatre of the oppressed. Gender and Education, 32,(1), 101-114.

Covid19.go.id. (2020). Situasi Virus Corona. Retrieved March 29, 2020, from https://www.covid19.go.id/situasi-virus-corona/

Fajrul, S. (2020, March 15). Dukungan Zenius untuk Kebijakan Belajar di Rumah di Tengah Penanggulangan Virus Corona. Retrieved March 29, 2020, from https://www.zenius.net/blog/23693/corona-belajar-di-rumah-kebijakan-pemda

Fleming, G. (2020, February 11). 5 Steps to Writing a Position Paper. Retrieved from https://www.thoughtco.com/how-to-write-a-position-paper-1857251

Freire, P. (1968). Pedagogy of the Oppressed. Verlag Herder

Guilford, C. (2001). Occasions for argumentative essays: Writing argumentative essays. Retrieved August 26, 2002 from the World Wide Web: http://www.powa.org/argufrms.htm. Previously adapted from: Hairston, M. (1982) A Contemporary Rhetoric (3rd ed.). Boston: Houghton Mifflin.

Kasih, A. P. (2020, March 16). Sekolah lawan Corona, Sekolahmu sediakan program belajar online gratis. Retrieved March 29, 2020, from https://www.kompas.com/edu/read/2020/03/16/154516171/sekolah-lawan-coronasekolahmu-sediakan-program-belajar-online-gratis

Kemdikbud. (2020, March 14). Cegah sebaran Covid19 di satuan pendidikan, Kemendikbud gandeng swasta siapkan solusi belajar daring. Retrieved March 20, 2020, from https://www.kemdikbud.go.id/main/blog/2020/03/cegah-sebaran-covid19-disatuan-pendidikan-kemendikbud-gandeng-swasta-siapkan-solusi-belajar-darin

Kemdikbud. (2019, December 11). Mendikbud tetapkan empat pokok kebijakan pendidikan merdeka belajar. Retrieved March 20, 2020, from https://www.kemdikbud.go.id/main/blog/2019/12/mendikbud-tetapkan-empatpokok-kebijakan-pendidikan-merdeka-belajar

Maragakis, L. L. (2020). Coronavirus, social distancing and self quarantine. Retrieved from https://www.hopkinsmedicine.org/health/conditions-and-

diseases/coronavirus/coronavirus-social-distancing-and-self-quarantine

Marope, P.T. M. (2017). Education: The key to development. Prospects, 47, 305-307.

Nugroho, R. S. (2020, March 14). Corona: 421 juta pelajar di 39 negara belajar di rumah, kampus di Indonesia Kuliah Online. Retrieved March 28, 2020, https://www.kompas.com/tren/read/2020/03/14/120000765/corona-421-jutapelajar-di-39-negara-belajar-di-rumah-kampus-di-indonesia

Panitia Buku Peringatan Taman Siswa 30 tahun (Ed.). (1952). Taman Siswa 30 Tahun. Yogyakarta: Panitia Buku Peringatan Taman Siswa 30 Tahun. 
Quipper. (2020). Ini dia konten gratis dari Quipper untuk guru dan siswa di seluruh Indonesia! \#BisaTetapBelajar. (2020, March 17). Retrieved March 29, 2020, fromhttps://www.quipper.com/id/blog/quipper-land/quipper-info/quipper-gratis/

Setiawan, B. (2019). Kemerdekaan belajar dahulu, gemar belajar kemudian. Retrieved December 12, 2019, from http:/ / temantakita.com/ kemerdekaan-belajar/

Suprapto, N. (2016). What should educational reform in Indonesia look like? - Learning from the PISA science scores of East-Asian countries and Singapore. Asia-Pacific Forum on Science Learning and Teaching,17(2),16.

Suprapto, N., Deta, U.A., Lestari, N.A., Kholiq, A., Adam, A.S., Mubarok, H., \& Jauhariyah, M.N.R. (2018). Pre-service physics teachers' understanding on total lunar eclipse: A response of supermoon on January 31 st 2018. Journal of Physics: Conference Series, $1108(1), 012097$.

Suprapto, N., Liu, W.-Y., Ku, C.-H. (2017). The implementation of multiple intelligence in (Science) classroom: From empirical into critical | [Daugialypio intelekto teorijos taikymas (Tiksliujų mokslų) pamokose: nuo empirinio iki kritinio požiūrio]. Pedagogika, $126(2), 214-227$.

UNESCO. (2020). Education emergencies. Retrieved March 28, 2020 from https://en.unesco.org/themes/education-emergencies/coronavirus-school-closures

Widianingtyas, H., \& Sadino, A. (2020, March 16). 8 situs gratis buat bantu kamu belajar di rumah. Retrieved March 29, 2020, from https://kumparan.com/millennial/8-situsgratis-buat-bantu-kamu-belajar-di-rumah-1t2FzIOfW8k 